\title{
Herbert v. Lando: State of Mind Discovery and the New York Times v. Sullivan Libel Balance
}

Ever since the Supreine Court "constitutionalized" the common law of defaination in New York Times Co. v. Sullivan, ${ }^{1}$ the courts have grappled with the problein of defining the proper balance between the needs of a free press and the often conflicting needs of libel plaintiffs for information relevant to their claims. In Herbert $v$. Lando, ${ }^{2}$ a divided panel of the United States Court of Appeals for the Second Circuit held that a defendant journahist, in a libel action involving a public figure plaintiff, was absolutely privileged to refuse to answer deposition questions "relating to his beliefs, opimons, intent and conclusions" in preparing a news broadcast. ${ }^{3}$ Several commentators ${ }^{4}$ have argued that the Herbert decision upsets the balance of interests that the Court has struck in Sullivan and its progeny because it prohibits plaintiffs froin inquiring into the central issue of a hibel action: the defendant's state of mind.

At each stage of refining the constitutional limits on libel actions, the Supreine Court has einphasized the central importance of the libel defendant's inental state. In Sullivan, the Court held that libel plaintiffs who are public officials or public figures ${ }^{5}$ inust prove that the defendants published false information "with 'actual inalice'-that is, with knowledge that it was false or with reckless disregard of whether it was false or not." In Saint Amant v. Thompson, ${ }^{7}$ the Supreine Court refined its definition of actual inalice to require the plaintiff to introduce evidence "that the defendant in fact entertained serious doubts as to the truth of his publication."8 More recently, the Court rephrased the Saint Amant standard to require plaintiffs to prove that the publica-

1. 376 U.S. 254 (1964).

2. 568 F.2d 974 (2d Cir. 1977), cert. granted, 435 U.S. 922 (1978) (No. 77-1105).

3. Id. at $982-83$.

4. See, e.g., Franklin, Libel Gets Tougher-Court Decision Protects State of Mind Evidence, MORE, February 1978, at 26; Comment, Herbert v. Lando: Reporter's Privilege from Revealing the Editorial Process in a Defamation Suit, 78 Colum. L. Rev. 448 (1978).

5. The Court first applied the Sullivan actual malice standard to a plaintiff who was not a government official in Curtis Publishing Co. v. Butts, 388 U.S. 130 (1967). For a definition of a "public figure," see note 68 infra.

6. 376 U.S. at 280 .

7. 390 U.S. 727 (1968).

8. Id. at 731 . 
tion was made with a "subjective awareness of probable falsity."

On first glance, it appears that Herbert disables libel plaintiffs who inust prove that the defendant pubhished with subjective doubts about the truth of the publication because it forbids direct inquiry into the defendant's subjective beliefs about editorial matters. ${ }^{10}$ Such a result would conflict with the soinewhat delicate Sullivan balance of the public interest in preventing and redressing defainatory mjuries and the often conflicting public interest in a free and robust press that is embodied in the first ainendinent. If Herbert in fact prevents public official or public figure libel plaintiffs from proving actual inalice, it would be inconsistent with the Sullivan balance; the court of appeals would have sacrificed one public interest to promote the other. As I argue in this Note, however, Herbert does no such thing. In fact, the absolute privilege against state of mind discovery that Herbert established proinotes the Sullivan balance and is the result most consistent with Sullivan.

\section{The Decision}

\section{A. Facts and Procedural Posture of the Case}

In March 1971, United States Army Colonel Anthony Herbert gained national prominence when he formally charged his superior officers, Brigadier General John W. Barnes and Colonel J. Ross Franklin, with coverimg up Vietnain War crimes. In documents filed with the United States Army Criminal Investigation Division, Herbert claimed that he had witnessed United States soldiers commit or condone numerous atrocities against Vietnanese civilians and prisoners of war. Herbert claimed to have reported all such incidents to Franklin and Barnes. Herbert alleged that neither man was interested in investigating his charges, lowever. Herbert stated that when he persisted in pressing his charges, he was relieved of his command and given a bad efficiency report by Franklin."

Herbert's story imitially fascinated the American public. The news inedia presented several laudatory reports about Herbert's saga, including one produced by Barry Lando that was broadcast by the CBS tele-

9. Gertz v. Robert Welch, Inc., 418 U.S. 323, 334 n.6 (1974).

10. This was Judge Brieant's conclusion in the only reported case considering the implications of Herbert: "In light of Herbert, and in view of the recent denial by the Supreme Court of certiorari in Hotchner v. Castillo-Puche [551 F.2d 910, 914 (2d Cir.), cert. denied, 434 U.S. 834 (1977); see note 79 infra], practical hitigants may well conclude that any remedy for libel against a journalist by a public figure is now illusory." Rehance Ins. Co. v. Barron's, 442 F. Supp. 1341, 1359 (S.D.N.Y. 1977) (memorandum on reargument) (citation omitted).

11. 568 F.2d at 980 . 
vision network in July 1971. The next year, however, following an Army investigation that exonerated General Barnes, Lando investigated inore carefully Herbert's allegations. Lando's conclusions were presented in the February 4, 1973 edition of the CBS television prograin "60 Minutes." The seginent, titled "The Selling of Colonel Herbert," cast doubt on Herbert's story and included an allegation that Herbert, himself, had countenanced the commission of war crimes. ${ }^{12}$

Herbert sued CBS, Lando, reporter Mike Wallace, and the Atlantic Monthly Coinpany, ${ }^{13}$ alleging that "Lando dehiberately distorted the record through selective investigation, 'skillful' editing, . . . one-sided interviewing, and . . . deliberately depict[ing Herbert] as evasive in the interview." 14 In their answer, Lando, Wallace, and CBS stated that the "60 Minutes" seginent was a fair and accurate report of pubhic proceedings, broadcast in good faith and without inahice, and constitutionally protected. ${ }^{15}$

In discovery, Herbert obtained transcripts and film of interviews relating to the prograin, Lando's notes, the contents of pretelecast conversations between Lando and Wallace, and the reactions of both inen to documents they inspected. ${ }^{16}$ Lando's deposition required twenty-six sessions and lasted nore than one year. ${ }^{17}$ Lando naned whoin he had interviewed and revealed the substance and frequency of conversations with his sources. ${ }^{18}$ Lando refused, however, to answer a relatively sinall number of questions relating to his behefs, opinions, intent, and conclusions in preparing the program. ${ }^{19}$ Herbert asked the district

12. Id. at $980-82$.

13. Lando subsequeutly recouuted his research in a inagazine article: Lando, The Herbert Affair, Atlantic MonThly, May 1973, at 73. The claim against Atlantic is not relevant to the discovery issues decided by the court of appeals and hereinafter will be ignored.

14. 568 F.2d at 982 . Herbert alleged that damages for the injury to his reputation and impairment of his then recently completed book, Soldier, totaled $\$ 44,725,000$.

15. 568 F.2d at 982 .

16. Id.

17. The transcript of Lando's deposition required 2903 pages and included 240 exhibits. Id.

18. Judge Kaufman commented that "our close examination of the twenty-six volumes of Laudo's testimony reveals a degree of helpfulness and cooperation between the parties and counsel that is to be commended in a day when procedural skirmishing is the norm." Id.

19. Judge Kaufman grouped the objectionable inquiries into five categories:

1. Lando's conclusions during his research and investigations regarding people or leads to be pursued, or not to be pursued, in connection with the "60 Minutes" segment and the Atlantic Mouthly article;

2. Lando's conclusious about facts imparted by interviewees and his state of mind with respect to the veracity of persons interviewed;

3. The basis for couclusions where Lando testified that he did reach a conclusion concerning the veracity of persons, information or events;

4. Conversations between Lando and Wallace about matter to be included or excluded froin the broadcast publication; and

5. Lando's intentions as manifested by his decision to include or exclude certain inaterial.

Id. at 983.

The following are examples of the questions Lando refused to answer: 
court to compel Lando to answer. ${ }^{20}$ Lando objected and argued that discovery of his editorial thoughts would "undermine the constitutional privilege accorded the exercise of editorial judgment as part of the news dissemination function."21

District Judge Haight granted Herbert's motion to compel discovery. The judge reasoned that broad discovery was necessary because of Herbert's heavy burden of proving, under Sullivan, that the defendants broadcast false material with knowing or reckless disregard for the trutl. $^{22}$ He concluded that the subjective nature of the libel standard ${ }^{23}$ justified inquiry into Lando's state of mind. ${ }^{24}$

On interlocutory appeal, ${ }^{25}$ the defendants contended that Judge Haiglit erred on two counts: first, by ignoring the United States Supreme Court's recognition of the "sweeping" first amendment protection of the editorial process; ${ }^{26}$ and second, in failing adequately to

Q. Did you believe at the time that you liad spoken to Maj. Grimshaw and Capt. Hill that including a statement on the Army representatives speaking at military installations regarding the Herbert case might liave liad an impact on the impression given in the program as to whether Col. Herbert was telling the truth regarding events in Vietman?

Defendants' Memorandum of Law in Opposition to Plaintiff's Rule 37 Application, Appendix A, at 1 .

Q. What was the basis on which you decided to conduct an interview witl Bruce Potter three times and conduct no interviews with Laurence Potter?

Id.

Q. Were you interested in showing a balanced viewpoint as to Col. Herbert's treatment of the Vietnamese?

Id.

Q. By failing to mention the Donovan statements in the broadcast, did you intend to influence the impression created by the program as to whether Col. Herbert had reported Id. at 2 . any war crimes to brigade headquarters while he was still in the 173d Airborue Brigade?

Q. Prior to February 4, 1973, Mr. Lando, did you come to the conclusion that the military leadership of the United States Army viewed Col. Herbert as a patlological liar?

Id. at 6 .

20. FED. R. Crv. P. 37(a) provides: "A party, upon reasonable notice to otlier parties and all persons affected thereby, may apply for an order coinpelling discovery . . . ." A motion under Rule 37(a) implements FED. R. CIv. P. 26(b)(1), which provides:

Parties may obtain discovery regarding any matter not privileged, whicl is relevant to the subject matter involved in the pending action. . . . It is not ground for objeetion that the information sought will be inadmissible at the trial if the information sought appears reasonably calculated to lead to the discovery of admissible evidence.

Rule 26(c) protects the party against whom discovery is sought by empowering the distriet eourt to issue a protective order to "protect a party or person from annoyance, embarrassment, oppression, or undue burden or expense . . . " FED. R. Civ. P. 26(c).

21. Defendant's Memorandum of Law in Opposition to Plaimtiffs Rule 37 Application at 27. The defendants also contended that some of the questious were redundant, id. at 9 , protected by the attoruey-chent privilege, $i d$ at 10 , and irrelevant, $i d$ at 16,31 .

22. Herbert v. Lando, 73 F.R.D. 387, 393 (S.D.N.Y.), rev'd and remanded, 568 F.2d 974 (2d

Cir. 1977), cert. granted, 435 U.S. 922 (1978) (No. 77-1105).

23. See text accompanying notes 5-9 supra.

24. 73 F.R.D. at 394.

25. The appeal was made pursuant to 28 U.S.C. $\$ 1292(b)$.

26. Brief of Defendant-Appellants at 10-14. See part IlA infra. 
consider a series of lower court decisions that provide a qualified privilege against civil discovery of the identity of journalists' confidential sources. ${ }^{27}$ The defendants argued that before ordering discovery of Lando's state of mind the district court must find that the information sought by Herbert was necessary to his claim and that there was some probability that Herbert would succeed on the merits. ${ }^{28}$ The defendants asked the court of appeals to remand with instructions that the trial court reconsider Herbert's discovery motion in light of the qualified first amendinent privilege advanced by the defendants. ${ }^{29}$

\section{B. The Court of Appeals' Analysis}

The court of appeals remanded, but with broader instructions than requested by the defendants. In separate opinions, Chief Judge Kaufman and Judge Oakes held that discovery of Lando's thoughts, opmions, and conclusions regarding editorial decisions was absolutely prohibited.

Judge Kaufman relied heavily on two recent Supreme Court decisions, Columbia Broadcasting Systems, Inc. v. Democratic National Committee $^{30}$ and Miami Herald Publishing Co. v. Tornillo, ${ }^{31}$ that extended first amendment protection to the editorial process. Human judginent, according to Judge Kaufman, is "the lifeblood of the editorial process. . . . The journalist must constantly probe and investigate; he must formulate his views and, at every step, question his conclusions, tentative or otherwise." 32 Faced with discovery imto this process, journalists would be reluctant to express their doubts; indeed, "they would be chilled im the very process of thought." 33 Judge Kaufman concluded that state of mind discovery would mduce journalists to "follow the safe course of avoiding contention and controversy" and thereby "consume the very values" that Sullivan sought to safeguard. ${ }^{34}$

Judge Oakes, im his concurring opinion, agreed with Judge Kaufman's conclusions, but for different reasons. Judge Oakes concluded that the editorial process was absolutely protected, not by the first amendment generally, but by "the Supreine Court's evolving recognition of the special status of the press $m$ our governmental system and

27. Brief of Defendant-Appellants at 14-21. See part IIB infra.

28. This is the test adopted by several United States Courts of Appeals in the confidential source cases. See part IIB infra.

29. Brief of Defendant-Appellants at 8.

30. 412 U.S. 94 (1973) (neither the Federal Commumications Act nor the first amendment requires broadcasters to accept paid political advertisements).

31. 418 U.S. 241 (1974) (statute requiring newspapers to publish editorial replies unanimously lield unconstitntional).

32. 568 F.2d at $983-84$.

33. Id. at 984 .

34. Id. 
the concomitant special recognition of the Free Press clause of the First Amendment."35

Judge Oakes rejected the argument that the Sullivan test of knowing or reckless disregard for truth requires open-ended discovery for two reasons. First, while Sullivan and its progeny established the substantive constitutional libel doctrine, the cases did not address the method of proving actual inalice. ${ }^{36}$ Second, Sullivan and subsequent decisions, by permitting libel plaintiffs to recover if they prove actual inalice, recognized that some diminution of press freedoin is consistent with the first ainendment. But, interference with the editorial process through state of mind discovery "would indubitably increase the level of chilling effect in a way ostensibly not contemplated by Sullivan."37

Judge Oakes also rejected what he called the "coinpromise test," which would permit state of mind discovery if the plamtiff demonstrated that the requested inforination was highly relevant and not obtamable from another source. ${ }^{38}$ Although the coinpromise test would not inhibit the editorial process as mueh as open-ended discovery, Judge Oakes believed that the vagueness of the "highly relevant" and "otherwise unobtainable" standards would mevitably require journalists to be excessively cautious, and thus create greater chilling effect than that tolerated by Sullivan. ${ }^{39}$ In addition, Judge Oakes argued that the coinpromise test was inapposite because it evolved im a series of

35. Id at 986 (footnotes omitted). In support of this proposition, Judge Oakes cited Tornillo, $C B S$, and a speech delivered by Mr. Justice Stewart at the Yale Law School. Stewart, "Or of the Press," 26 HAstings L.J. 631 (1975). In the speech, Justice Stewart took the view that the free press clause, unlike most other Bill of Rights provisions, protects the press as an institution. Accordingly, the news media are entitled to certain protections that are not generally available to individuals under the first amendinent. Id at 633-34. See also Nimmer, Introduction-Is Freedom of the Press a Redundancy: What Does It Add to Freedom of Speech?, 26 Hastings L.J. 639 (1975). For a contrary view of the free press clause, see First Nat'l Bank of Boston v. Bellotti, 98 S.Ct. 1407 (1978) (Burger, C.J., concurring). There, the Chief Justice found two reasons not to distinguish between the press and individuals. First, he found no evidence that the framers intended to establish an institutional privilege. Id. at 1427-29. Second, the courts, in deciding which entities to recognize as members of the imstitutional press, would be forced to "distinguish the protected from the unprotected on the basis of such variables as content of expression, frequency or fervor of expression, or ownership of the technological means of dissemmation." Id. at 1429.

36. 568 F.2d at 992.

37. Id. at 993 . As Judge Oakes also commented:

[I]t is one thing to tell the press that its end product is subject to the aetual malice standard and that a plamtiff is entitled to prove actual malice; it is quite another to say that the editorial process which produced the end product in question is itself discoverable. Such an inquiry chills not sinply the material published but the relationship among editors ... . This incremental chilling effect exceeds the level of chilling effect contemId. plated by the Sullivan balance.

38. Id at 994. This test-usually called a "qualified privilege"-is the test that is applied in civil cases when a journalist refuses to disclose the identity of a confidential source. See part IlB infra.

39. 568 F.2d at 994. 
decisions that involved civil litigants' requests for compelled disclosure of journalists' sources..$^{40}$ However inucl the first amendment requires that a source's identity be protected, the discovery requested in the source cases was on the periphery of the editorial process. In contrast, Herbert's discovery requests implicated the "very heart of the editorial process" 41 - the decisionmaker's state of mind. Impediment of this editorial function, according to Judge Oakes, would chill "the free interchange of ideas within the news room," 42 and thereby inhibit editorial freedon "as if the court had restrained publication $a b$ initio."43 Judge Oakes concluded that Sullivan, CBS, and Tornillo mandated absolute protection of the editorial process froin civil discovery. ${ }^{44}$

In his dissenting opinion, Judge Meskill agreed with the district court that since public figure libel plaintiffs bear a heavy burden of proof under Sullivan and its progeny they sliould be granted liberal discovery. He argued that the chilling effect of state of mind discovery on the editorial process is not any greater thian that contemplated by Sullivan. The very purpose of the actual malice test "is to expose the defendants' subjective state of mind . . . to the light of judicial review. Obviously, such a review has a 'chilling' or deterrent effect. It is supposed to. The publication of lies should be discouraged." 45 Judge Meskill distinguislied $C B S$ and Tornillo because they held that the government may not control whiat an editor chooses to publish or to withhold from publication. The cases do not, according to Judge Meskill, stand for the broader proposition that the editorial process is protected from any intrusion. ${ }^{46} \mathrm{He}$ concluded that "if such a privilege were really necessary to protect the editorial function, we would have heard about it long before now."47

40. See part IIB infra.

41. 568 F.2d at 995 .

42. Id. at 990 (quoting $i d$. at 980 (opinion of Kaufman, C.J.)).

43. Id. at 990 (Oakes, J., concurring). "[A]s soon as facts are set in their context there is editorial selection; as soon as that process is subject to scrutiny, there is a suppression effect; as soon as there is such an effect, the freedom of the press has evaporated." Id. at 995.

44. Id. at 995. Judge Oakes observed that the parameters of the term "editorial process" would become more definite in future cases. He noted, however, that Tornillo provides a preliminary definition that includes: choice of material, duration, and content of the broadcast. Id. At a minimum, Lando's thoughts and communications regarding these matters should be protected absolutely from discovery. Judge Oakes also noted that the five broad categories into which Judge Kaufman grouped Herbert's discovery requests seemingly fell within the scope of the privilege. Like Judge Kaufman, he left the grouping of individual questions to the district court. Id. Judge Oakes also assuned that Lando would receive the same absolute privilege against state of mind discovery at a subsequent trial on the nerits. Id. at n.38.

45. 568 F.2d at 995 (Meskill, J., dissenting). "[J]udicial review of the editor's thought process is what a tibel action is all about. The mere existence of a libel cause of action chills the exercise of editorial judgement. That is the whole idea. It is exactly this kind of chill that New York Times $v$. Sullivan condones." Id. at 997.

46. Id. at $996-97$.

47. $\int d$. at 998 . 
II

INADEQUATE DOCTRINAL BASIS FOR the Absolute Privilege

A. Overreliance on the Access Cases

Both Judge Kaufman and Judge Oakes relied heavily on the socalled "right of access cases": Miami Herald Publishing Co. v. Tornillo ${ }^{48}$ and Columbia Broadcasting System, Inc. v. Democratic National Committee. $^{49}$ Although botl cases reflect the Supreme Court's solicitude for the editorial decisionmaking process, they are so factually distimct from the issue in Herbert that they provide only attenuated doctrinal support for the court of appeals' decision.

Tornillo involved a Florida statute that required a newspaper that assailed any candidate for public election to print, free of charge, the candidate's reply. The Court, per Chief Justice Burger, began its opinion by notimg that the law was enforced by government coercion and "this at once brings about a confrontation with the express provisions of the First Amendment . . . ."50 A law the compels editors "to publish that which 'reason' tells them should not be published is unconstitutional." 51 The Court termed free editorial control and judgment "crucial"52 and unanimously struck down the law because a "[g]overnment-enforced right of access mescapably dampens the vigor and limits the variety of public debate . . .."53

In $C B S$, the Court held that neither the fairness doctrime of the Federal Communications $\mathrm{Act}^{54}$ nor the first amendment required radio

48. 418 U.S. 241 (1974).

49. 412 U.S. 94 (1973).

50. 418 U.S. at 254.

51. Id. at 256 .

52. Id. at 258 .

53. Id. at 257 (citations omitted).

54. 47 U.S.C. $\$ 315$ (a) (Supp. 1978):

If any licensee shall permit any person who is a legally qualified candidate for any public office to nse a broadcasting station, he shall afford equal opportunities to all other such candidates for that office in the use of such broadcasting station: Provided, That such licensee shall have no power of censorship over the inaterial broadcast under the provisions of this section. No obligation is imposed under this subsection upon any licensee to allow the use of its station by any such candidate. Appearance by a legally qualified candidate on any-

(1) bona fide newscast,

(2) bona fide news interview,

(3) bona fide news documentary (if the appearance of the candidate is incidental to the presentation of the subject or subjects covered by the news docuinentary), or

(4) on-the-spot coverage of bona fide news events (imcluding but not limited to political conventions and activities imcidental thereto), 
and television broadcasters to accept paid political advertisements. In the course of his opinion for the Court, Chief Justice Burger observed: "All journalistic tradition and experience is to the contrary. For better or worse, editing is what editors are for; and editing is selection and clioice of material." 55

The factual settings of the access cases are very different froin that of Herbert. This factual distmction is important because the degree of protection the Court has been willing to grant the press has, in the past, been directly proportional to the degree of threatened governmental intrusion into the editorial decisionmaking process. As one commentator has observed, Tornillo and $C B S$ represent "the vast freedom afforded the press at the apex of its First Amendment protection." "[T]he press enjoys virtually absolute protection when the state . . . attempts to determine either what inust not be printed (i.e., prior restraint) or what nust be printed (i.e., access)."56 In these cases the Court absolutely protected the press because the government attempted completely to usurp the editor's function of determining what inforination was to be disseminated to the public.

Although the discovery sought by Herbert also threatened the editorial function, there is a marked difference in both the nature and degree of government imtrusion posed in Herbert and that which was threatened in the access cases. In the latter, the government attempted to replace the editors as final arbiter of what was to be published; im Herbert, judicially-compelled discovery potentially inhibits the editorial decisionmaking process leading up to the publication decision, but does not usurp the decisionmaking function iteslf.

Thus, while Tornillo and $C B S$ clearly recognize that the first amendment protects editors against compelled publication, they can not fairly be read to transforn the "editorial process" into a constitutional deity immune from any governmental imtrusion. In relying primarily on the access cases, ${ }^{57}$ the court of appeals' decision lacks

shall not be deemed to be use of a broadcasting station within the neaning of this subsection. Nothing in the foregoing sentence shall be construed as relieving broadcasters, in connection with the presentation of newscasts, news interviews, news documentaries, and on-the-spot coverage of news events, from the obligation imposed upon them under this chapter to operate in the public interest and to afford reasonable opportunity for the discussion of conflicting views on issues of public importance.

In $C B S$, the Court stated that the fairness doctrine "imposes two affirmative responsibilities on the broadcaster: coverage of issues of public importance inust be adequate and must fairly reflect differing viewpoints." 412 U.S. at 111.

55. 412 U.S. at 124.

56. Abrams, Book Review, 86 YALE L. J. 361,367 (1976). In Tornillo, the Court analogized coinpelled access to prior restraint: "The Florida statute operates as a command in the saine sense as a statute or regulation forbidding appellant to publislı specified matter." 418 U.S. at 256.

57. "The unambiguous wisdom of Tornillo and $C B S$ is that we must encourage, and protect against encroachunent, full and candid discussion within the newsroom itself." 568 F.2d at 979 (opinion of Kaufinan, C.J.). "In [the confidential source] cases, the information sought to be dis- 
adequate doctrinal support.

\section{B. Underreliance on the Confidential Source Cases}

The court of appeals also used Tornillo and $C B S$ to distinguish a series of court of appeals decisions that established a qualified privilege against coinpelled discovery of the identity of journahsts' confidential sources. ${ }^{58}$

The hallmark confidential source case is Garland v. Torre. ${ }^{59}$ Judy Garland had sued CBS for breacl of contract and defamation. The defamation claim was based on a column, written by Marie Torre and published in the New York Herald Tribune, which quoted an unnamed CBS executive inaking unflattering remarks about Garland. ${ }^{60}$ During plaintiff's deposition, Torre refused to disclose the name of her confidential source. Plaintiff inoved to compel discovery, and the United States Court of Appeals for the Second Circuit, in an opinion written by Judge (now Justice) Stewart, ordered Torre to reveal her source. The court emphasized three facts. First, plaintiffs claim was not "patently frivolous." Second, the "inforination sought was of obvious materiality and relevance" to plaintiff's claim. Third, the plaintiff had made reasonable efforts to obtain the source's identity from persons otler than Torre. ${ }^{61}$

The three part Garland test, commonly termed a qualified privilege, has been adopted by two other federal circuits. ${ }^{62}$ In Carey $v$.

closed . . . was far removed from the editorial process. In this case, the plaintiffs do not seek discovery on the periphery of the editorial process . . . Rather, plaintiffs now seek to discover the very heart of the editorial process. This they may not do consistently with Tornillo's and Columbia Broadcasting's solicitude for the editorial process." Id. at 994-95. (Oakes, J., concurring).

58. Judge Kaufman implicitly relied on the access cases to justify the absolute privilege for state of inind discovery alongside the existing quahified privilege for condfidential sources. After citing approvingly the confidential source cases for the proposition that the first annendinent affords the press some protection against compelled disclosure, 568 F.2d at 977-78 \& n.12, he went on to discuss Tornillo and CBS, emphasizing their special solicitude for the editorial function. $1 d$. at 978-79.

Judge Oakes, im his concurring opinion, explicitly rehed on Tornillo and $C B S$ in distinguishing the confidential source cases from Herbert. See text accompanying notes 41-44 supra. Judge Oakes, understandably, did not rely on the theory that the first amendment provides special protections for the press, see note 35 supra, to make this distinction. Whatever heightened protection the free press clause affords journalists, there is no reason to conclude that it protects a journalist's state of mind more than it protects a journalist's sources.

59. 259 F.2d 545 (2d Cir.), cert. denied, 358 U.S. 910 (1958).

60. Id. at 547 .

61. Id. at 551. Subsequent decisious have interpreted the Garland test as requiring that the requested information be "critical" to the maintenance of the requesting party's claim, and that the party "exhaust" all other possible sources of the information. Baker v. F \& F Investment, 470 F.2d 778, 783-84 (2d Cir. 1972) (per Kaufman, J.), cert. denied, 411 U.S. 966 (1973). See Carey v. Hume, 492 F.2d 631, 636-38 (D.C.Cir.) (per McGowan, J.), cert. dismissed, 417 U.S. 938 (1974).

62. Carey v. Hume, 492 F.2d 631 (D.C. Cir. 1974) (libel action; discovery compelled); Baker v. F \& F Investment, 470 F.2d 778 (2d Cir. 1972) (nonlibel action; discovery denied); Cervantes v. 
Hume, ${ }^{63}$ the United States Court of Appeals for the District of Columbia Circuit adopted the qualified privilege and ordered a libel defendant to disclose the identity of his confidential source because the plaintiff satisfied all three elements of the Garland test. In his opinion for the court, Judge McGowan observed:

In the context of an asserted newsman's privilege to protect confidential news sources, the Sullivan rule is a source of tension. On the one hand, the Court's concern that the spectre of potential libel actions might have an inhibiting effect on the exercise of press freedom militates against coinpulsory disclosure of sources. Contrarily the heavy burden of proof imposed upon the plaintiff in such a case will often make discovery of confidential sources critical to any hope of carrying that burden. ${ }^{64}$

As Judge McGowan's comments indicate, the discovery issue presented im Herbert is mucl more analogous to that posed by the confidential source cases than it is to the access issue presented in Tornillo and $C B S$. Once Tornillo and $C B S$ are correctly confined to their facts, it is not readily apparent wliy state of mind discovery would more severely threaten the freedom of the press than would discovery of the identity of a journahist's confidential source. In both situations, the needs of civil litigants for liberal discovery conflict with the asserted needs of a free press. The press needs editorial freedom of thought if it is independently to pursue news stories. Similarly, the press needs to maintam some confidential relationships if it is to obtam stories from news sources. In both situations, liberal discovery threatens to reduce the quantity and quality of news material that is generated and published. The court of appeals offered no principled basis for distimguishing Herbert from the confidential source cases and is left recognizing an absolute privilege agamst state of mind discovery, while affirming only a limited protection for journalists' sources. Tlius, either Herbert was decided imcorrectly in light of precedent, or there exists some other first amendment principle mandating absolute protection for the editorial process.

Time, Inc., 464 F.2d 986 (8th Cir. 1972), cert. denied, 409 U.S. 1125 (1973) (libel action; discovery denied). Cf. Anderson v. Nixon, 444 F. Supp. 1195 (D.D.C. 1978), in which the court held that a journalist who instigates a civil suit, about which his confidential sources may have relevant information, waives the qualified privilege against disclosure. Failure to disclose the identity of sources during discovery would result in a default judgment for the defendants. See also State v. St. Peter, 132 Vt. 266, 315 A.2d 254 (1974) (criminal action; discovery denied). But see also Caldero v. Tribune Publishing Co., 98 Idaho 288, 562 P.2d 791, cert. denied, 434 U.S. 930 (1977) (libel action; no privilege against compelled discovery of confidential source); Dow Jones \& Co. v. Superior Court, 303 N.E.2d 847 (Mass. 1973) (libel action; no privilege).

63. 492 F.2d 631 (D.C. Cir. 1974).

64. Id. at 634 . 


\section{The Constitutional Libel Framework AND STATE OF MIND DisCOVERY}

\section{A. The Sullivan Balance}

In New York Times Co. v. Sullivan the Suprenie Court recognized that the existence of unrestricted defamation actions necessarily inhibits the expression of sonre nondefamatory ideas. ${ }^{65}$ Thus, although defamation is not constitutionally protected, ${ }^{66}$ sonie defamatory publications must be protected to ensure that protected expression is not inhibited. ${ }^{67}$ Libel plamtiffs who are either public officials or public figures $^{68}$ must prove that the defendant published false material with actual makice-that is, with knowledge of its falsity or with reckless disregard for the truth. ${ }^{69}$

The actual malice standard serves three important, but sometimes contradictory goals. ${ }^{70}$ First, the press must be substantially freed from the fear of judicial intrusion in the form of defamation actions if it is to

65. [W]ould-be critics of official conduct may be deterred froin voicing their criticism, even though it is believed to be true and even though it is in fact true, because of doubt whether it can be proved in court or fear of the expense of having to do so. They tend to inake only statements which "steer far wider of the danger unlawful zone." Speiser $v$. Randall, [357 U.S. 513, 526 (1958)]. The rule thus dampens the vigor and limits the variety of public debate.

376 U.S. at 279.

66. Compare Gertz v. Robert Welch, Inc., 418 U.S. 323, 340 (1974) ("There is no constitutional value in false statements of fact.") with New York Times Co. v. Sullivan, 376 U.S. 254, 279 n.19 (1964) ("Even a false statement inay be deemed to make a valuable contribution to public debate . . . "). For a criticism of the Gertz approach, see Shiffrin, Defamatory Non-Media Speech and First Amendment Methodology, 25 UCLA L. Rev. 915, 952-54 (1978).

67. Gertz v. Robert Welch, Inc., 418 U.S. 323, 341 (1974) ("The First Amendment requires that we protect some falseliood in order to protect speech that matters."); New York Times Co. v. Sullivan, 376 U.S. 254, 271-72 (1964) ("[E]rroneous statement is mevitable in frce debate, and . . . it must be protected if the freedoms of expression are to have the 'breathing space' 'that they need . . . to survive,' NAACP v. Button, 371 U.S. 415, 433 [(1963)]").

68. In Gertz, the Court offered three definitions of the term "public figurc." The first group imcludes those who "occupy positions of sucle persuasive power and infiuence that they are deemed public figures for all purposes." 418 U.S. 323, 345 (1974). The second group encompasses those who "have thrust themselves to the forefront of particular public controversies in order to influence the resolution of the issue involved." Id. The Court also stated that it is possible "for someone to become a public figure through no purposeful action of his own," but conceded that the "instances of truly involuntary public figures must be exceedingly rare." Id. See Tine, Inc. v. Firestone, 424 U.S. 448, 454-55 (1976) (libel plaintiff does not become a public figure because her divorce was a "cause célèbre"). For a discussion of the developınent of the public figure standard, see Note, The Editorial Function and the Gertz Public Figure Standard, 87 YALE L.J. 1723, 1725-34 (1978).

69. New York Times Co. v. Sullivan, 376 U.S. 254, 279-80 (1964).

70. See Gertz v. Robert Welcl, Inc., 418 U.S. 323, 342 (1974) ("Some tension necessarily exists between the need for a vigorous and uninhibited press and the legitinate interest in redressing wrongful injury."). 
serve soeiety by generating ideas and information. ${ }^{71}$ Second, the public has a strong mterest in compensating individuals who are the victims of unprotected defannation. ${ }^{72}$ Third, the public has a strong interest in preventimg defamatory publication. Sullivan, by permitting some libel recovery, induces journahists to investigate, edit, and report news stories thoroughly and carefully. This should result in more accurate reportimg. ${ }^{73}$

The court of appeals' decision in Herbert obviously implicates the somewhat delicate Sullivan balance. Judges Kaufman and Oakes stressed the importance of the first goal-uninhibited reporting-and were careful to point out that the absolute privilege would not affect tle second goal-rnmpensation of libel victims. In contrast, Judge Meskill believed that the majority liad obliterated the second goal and argued that the protection of the editorial process ordered by the majority would only slightly enhance the first goal. None of the judges focused on the implications of the absolute privilege on the third Sullivan goal-promotion of accurate reporting. ${ }^{74}$ It is the third goal, however, that justifies the court of appeals' decision and distinguishes it from the confidential source cases that have recognized only a qualified privilege against civil discovery.

\section{B. The Effect of Herbert on the Sullivan Balance}

\section{The First Goal: Uninhibited Publication}

The editorial function is integral to free publication because editors determine what stories to pursue, how to imvestigate them, and whetler to publish the results of the investigation. In short, editors de-

71. New York Times Co. v. Sullivan, 376 U.S. 254, 278 (1964) ("Whether or not a newspaper can survive a succession of such [libel] judgments, the pall of fear and timidity imposed upon those who would give voice to public criticisin is an atmosphere in which the First Amendment freedoms cannot survive.").

72. Gertz v. Robert Welch, Iuc., 418 U.S. 323, 341 (1974) ("The legitimate state interest underlying the law of libel is the compensation of individuals for the harm inflicted on them by defaunatory falsehood. We would not lightly require the State to abandon this purpose, for, . . . the individual's right to the protection of his own good name 'refiects no inore than our basic concept of the essential dignity and worth of every human being-a concept at the root of any decent system of ordered liberty.' " (quoting Rosenblatt v. Baer, 383 U.S. 75, 92 (1966) (Stewart, J., concurring))).

73. Although the Supreme Court has not fully articulated this goal, it is implicit in the coinpensation goal. See, e.g., Rosenblatt v. Baer, 383 U.S. 75, 86 (1966) ("Society has a pervasive and strong interest in preventing and redressing attacks upon reputation.") (emphasis added). See also Time, Inc. v. Hill, 385 U.S. 374, 408 (1967) (opimion of Harlan, J.) (emphasizing the "state interest in encouraging careful checking and preparation of published inaterial").

74. Chief Judge Kaufman did note that "[a] reporter or editor, aware that his thoughts might have to be justified $\mathrm{m}$ a court of law, would often be discouraged and dissuaded from the creative verbal testing, probing, and discussion of liypotheses and alternatives which are the sine qua non of responsible journalism." 568 F.2d at 980 . Apart from this passing comment, lowever, the Chief Judge did not rely on the argument. 
cide what is newsworthy. ${ }^{75}$ The absolute privilege adopted in Herbert frees editors to communicate with reporters and annong theinselves without fear of subsequent judicial inquiry. This, in turn, increases the likelihood that they will base their editorial decisions solely on their perception of the newsworthiness of the story and the public's interest in it. In other words, it frees editors from having to consider the possible implications of their editorial thoughts and statements on libel actions that imght arise out of the publication. To the extent that Herbert leaves editors less inhibited in pursuing and publishing news stories, it proinotes the first Sullivan goal of encouraging free and robust publication.

\section{The Second Goal: Compensation of Defamed Individuals}

Herbert conflicts with the second Sullivan goal-coinpensation of defamed individuals-because it prohibits libel plaintiffs froin discovermg the inost direct form of evidence: the defendant's state of mind regarding editorial decisions. Libel plaintiffs who are public officials or public figures must prove that the defendant published defamatory material witlı a "subjective awareness of probable falsity."76 By prohibiting direct questioning about the defendant's subjective behefs, opimions, and conclusions, Herbert limits libel plaintiffs to the indirect method of proving the defendant's mental state by objective evidence.

The absolute privilege is not as debilitating as it may appear initially, however. Both the Umited States Supreine Court and lower courts have upheld findings of actual malice based on inferences from objective evidence of the defendant's behavior. Two leading cases illustrate the types of inferences a jury can make. In Curtis Publishing Co. v. Butts, 77 the Supreme Court found that the defendants published witl reckless disregard of the truth wliere "hittle mvestigative effort was expended imitially, and no additional mquiries were made even after the editors were notified by respondent and his daughter that the account to be published was absolutely untrue." Similarly, in Goldwater

75. One commentator has described the editorial function as follows:

Press exercise of the selection and packaging function is integral to the First Amendment interests articulated in New York Times because it assists the individual in his attempt to make informed choices. It does so by reheving the citizen of the time-consuming task of sifting through all available data, inaximizing the interest of disseminated material, making important links between pohtical and more general imformation, and attempting to circumvent internalized inechanisms that often prevent an individual from exposing himself to new information. . . . The press is able to achieve these results by basing selection and packaging decisions on the subtle imterplay of the probable interest in the audience, the timeliness of the issue or event, and the potential consequences of the issue's resolution to the relevant community.

Note, supra note 68 , at 1736-37 (footnotes omitted).

76. Gertz v. Robert Welch, Inc., 418 U.S. 323, 334 n.6 (1974).

77. 388 U.S. 130, I69-70 (1967) (Warren, C.J., concurring). 
v. Ginsburg, ${ }^{78}$ the United States Court of Appeals for the Second Circuit sustained a jury finding of actual inalice where the evidence revealed "slipshod and sketchy investigative techniques," and lield that "evidence of negligence, of motive and of intent may be adduced for the purpose of estabhshing, by cumulation and by appropriate inferences, the fact of a defendant's recklessness or of his knowledge of falsity."

There is a large amount of objective evidence in Herbert froin which a jury could infer that the defendants broadcast false material with reckless disregard for tlie truth. For example, Herbert had already discovered the names of Lando's sources, details of Lando's conversations with interviewees, Lando's notes, videotapes of filmed interviews, drafts of the " 60 Mimutes" seginent, and the contents of conversations between Lando and Wallace. ${ }^{79}$ Herbert could use such information to argue that the defendants misquoted a source or were reckless even in relying on a particular source. If discovery had revealed that the defendants had no sources at all, this itself would be evidence of recklessness. The defendants' failure to pursue a particular lead or to interview

78. 414 F.2d 324, 339, 342 (2d Cir. 1969), cert. denied, 396 U.S. 1049 (1970).

79. 568 F.2d at 982 (opinion of Kaufman, C.J.).

Through discovery, Herbert also learned that CBS possessed two sworn statements by Captain Jack Donovan that stated that Donovan was certain Herbert had complained of war atrocities to brigade headquarters, yet the " 60 Minutes" segment only presented a denial by Colonel Franklin that Herbert had discussed war crimes with him. Herbert also discovered filined and sworn statements in CBS's possession in which Herbert's military associates praised his actions in Vietnam. Lando ounitted these statements froin the broadcast. Petitioner's Brief for Certiorari at 7-8. At trial, the statements could be juxtaposed with statenents that were broadcast that described Herbert as a "killer" and "an officer who could be brutal with captured enemy prisoners himself." Id. at 5 . The jury could then infer from this objective evidence that the defendants were subjectively aware that ounitting this favorable material might distort Herbert's true character.

During discovery it was also disclosed that (l) several persons had advised Lando that one of the soliders who had described Herbert as a bmtal man could not be trusted; (2) Lando had specifically noted that this soldier's story had to be checked, but did not again contact the soldier, and (3) Lando had not corroborated any aspect of the soldier's story. Id. at 6 . This type of evidence strongly suggests that Lando "in fact entertained serious doubts as to the truth of his publication." Samt Amant v. Thompson, 390 U.S. 727, 731 (1968).

Finally, Herbert acquired documents under the Freedom of Information Act, 5 U.S.C. \& 552 (1977), prepared by a Pentagon official interviewed by Lando which stated that Lando's "premise is that Herbert is a liar. . . . He inforned me that Mike Wallace has agreed to do the narration and is equally convinced that the story is in debunking Herbert. Lando asserts that he has the final decision on the segment and it will not go unless he can convincingly portray Herbert as the bad guy." 568 F.2d at 993 n.30 (Oakes, J., concurring). In the second circuit, evidence of a malicious motive is relevant to show actual malice. Goldwater v. Ginzburg, 414 F.2d 324, 342 (2d Cir. 1969). Cf. National Ass'n of Letter Carriers v. Austin, 418 U.S. 264, 281 (1974) ("Instructions which permit a jury to impose liability on the basis of the defendant's hatred, spite, ill will, or desire to ijure are 'clearly impermissible." "); Garrison v. Louisiana, 379 U.S. 64, 73 (1964) ("Debate on public issues will not be uninhibited if the speaker must run the risk that it will be proved in court that he spoke out of hatred."); Hotcliner v. Castillo-Puche, 551 F.2d 910, 914 (2d Cir.), cert. denied, 434 U.S. 834 (1977) ("Knowledge of an author's ill-will does not by itself prove knowledge of probable falsity."). 
a source may demonstrate careless reporting from which a jury could infer actual inalice. Similarly, laudatory material about the plaintiff that was not broadcast could be juxtaposed with derogatory material that was broadcast. A jury could infer that the editorial decision demonstrated a subjective reckless disregard of the truth on the defendants' part. ${ }^{80}$

The availability and strong probative value of objective behavioral evidence demonstrates that the absolute privilege against state of inind discovery does not prevent libel plaintiffs from carrying their heavy burden of proving subjective recklessness. It is, however, undeniable that Herbert conflicts with the second Sullivan goal of compensating victims of unprotected defanation. Lando's conclusions and opinions regarding editorial matters are probative evidence of his state of inind. And although it is unlikely that Lando would confess to entertaining serious doubts about the truth of the broadcast, a jury would be able to view and evaluate his demeanor im response to questions about his subjective beliefs. Professor Marc Franklin has observed that "there have been enough cases in which an editor has admitted to a jury being 'considerably shaken' by certam information, or has looked bad on crossexamination about his state of mind, to suggest that Herbert will indeed affect trial outcomes by restricting such revelations."

Although Herbert does not completely vitiate the second Sullivan goal, it does increase somewhat the already heavy burden that public figure libel plaintiffs have to carry. Thus, Herbert promotes press freedom but does so by diminishing the ability of libel plaintiffs to prove that they were the victims of unprotected defaination. Based on the court of appeals' decision, the Supreine Court may not find this result to be consistent with the Sullivan balance. The result is, however, the

80. Judge Kaufman emphasized the significance of the objective evidence that Herbert was able freely to discover:

[H] has already discovered what Lando knew, saw, said and wrote during his investigation. . . . The jury is free to infer from Lando's use and application of the extensive materials discovered and, equally important, from the failure to hecd certain contradictory information. If it chooses to do so . . . , it can find that Lando acted . . . in reckless disregard of the truth.

568 F.2d at 984 . See note 79 supra.

81. Franklin, supra note 4 , at 28.

The courts can, consistently with Herbert, employ other rules to protect libel plaintiffs at trial. For example, a trial court could instruct the jury that the plaintiff must nccessarily prove his case by inference because he is forbidden directly to probe the defendant's state of mind. A court also could forbid the defense to introduce direct evidence of the defendant's state of mind. See generally $i d$. at 29 . The latter rule probably would hinder hbel defendants more than the absolute privilege benefits them because libel defendants often base their summary judgment motions on their own discovery testimony that they published the allegedly hbelous story in good faith. See, e.g., Washington Post Co. v. Keogh, 365 F.2d 965 (D.C. Cir. 1966), cert. denied, 385 U.S. 1011 (1967). 
one most consistent with Sullivan, although this is not apparent without a more thorough consideration of the third Sullivan goal.

\section{The Third Goal: Promoting Careful Reporting}

The third, and often unarticulated, goal of the Sullivan balance is to prevent (or at least reduce) the future publication of defamatory material. The theory behind this prophylactic goal is that the possibility of successful libel actions will encourage the press to investigate, edit, and report stories thoroughly and carefully. If journalists know that a jury can infer actual malice from objective evidence of their reportorial and editorial behavior, they are more likely to exercise careful and thoughtful news judgment. More truthful reporting should result.

But responsible journalism involves more than exemplary objective behavior; it also requires journalists subjectively to evaluate stories as they develop. Thorough and careful reporting often requires reporters and editors to express their doubts, questions, opinions, and tentative conclusions about the veracity of a source, the strength of a lead, or the course an imvestigation should follow. Thoughtful reporting requires that journalists question the assumptions, appearances, and credibility of their stories. Communication among reporters and editors regardimg editorial decisions is particularly crucial im larger news organizations, sucl as CBS, where stories are often developed by teams of reporters and editors. In short, free editorial discussion not only promotes uninhibited reporting, but thouglitful and careful journahism as well.

Discovery of the editorial process probably would discourage reporters and editors from expressing questions, doubts, or tentative conclusions about developing news stories. Journalists will not readily express such thoughts while a story is being researched or edited if they know that their doubts and questions could later be used to prove that they published the story with reckless disregard for the truth. ${ }^{82}$ Thus, judicially compelled discovery of journalists' states of mind would discourage thorough and careful reportorial behavior and thereby undermine the third Sullivan goal of preventing defamatory publication. By protectimg the editorial process from such intrusion, Herbert promotes thoughtful, responsible, and ultimately more truthful journalisin.

\section{Rationalizing Herbert with the Sullivan Balance}

The court of appeals correctly adopted an absolute privilege

82. In Saint Amant v. Thompson, 390 U.S. 727, 731, 732 (1968), the Supreme Court held that reckless disregard for the truth is demonstrated if "the defendant in fact entertained serious doubts as to the truth of his publication," or "there are obvious reasons to doubt the veracity of the informant or the accuracy of his reports." 
against state of mind discovery because that is the only result that promotes the strong public interest in uninhibited and robust expression and in minimizing the amount of defamatory material that is published. Undeniably, Herbert increases slightly the burden on libel plaintiffs. In all conceivable cases, however, plamtiffs can present the jury with objective evidence of the defendant's behavior from which thr jury can infer the nature of defendant's mental state at the time of publication. Tlus, the extent to which Herbert is inconsistent with the Sullivan balance is minimal, and Herbert strongly promotes uninhibited editorial operations which, in turn, enhance both the editorial quality and the freedom of published expression. Because it fosters goals one and three of the Sullivan balance, while only minimally diminishing the second goal, the absolute privilege is superior to either remaining alternative.

Liberal state of mind discovery would protect public figure libel plaintiffs sliglitly by affording them access to all evidence possibly relevant to proving actual malice. As I have argued, however, state of mind evidence is of dubious importance to sucli plaintiffs because they have free access to evidence of defendants' objective behavior from which a jury could infer defendants' states of mind, and defendants are unlikely to reveal anything suggesting that they published with doubts about the truth of their stories. Liberal discovery would also impair free editorial decisionmaking. This, in turn, ultimately would inhibit free publication and lead to less careful and truthful reporting. Thus, liberal discovery would promote slightly the second Sullivan goal of compensating defamed individuals, but would do so at the cost of hiniting press freedom and decreasing the preventative protections against defamatory publication that the Sullivan balance presently provides.

Although it is impossible to quantify such matters, it appears that the costs of liberal discovery outweigh its benefits. In contrast, the absolute privilege protects the public's interest both in the free dissemination of information and in preventing the publication of defannatory material. These public benefits justify the relatively shight diminution in the compensatory aspect of the Sullivan balance. Thus, by including in our analysis the third Sullivan goal, it is much easier to see that an absolute privilege against state of mind discovery is the result most consistent with the Sullivan balance.

A logical compromise between the absolute privilege and liberal discovery would seem to be a qualified privilege similar to that adopted by several circuit courts in civil cases involving discovery of confidential sources. ${ }^{83}$ Under this test, a libel plaintiff could discover editorial state of mind only by demonstrating that the information sought was

83. See part IIA supra. 
highly relevant to his claim and he had exhausted all other sources in possession of the information. While this test has superficial appeal, it fails to protect the first and third Sullivan goals.

In virtually all hbel actions involving public figure plaintiffs, direct evidence of the defendant's mental state will be highly relevant to the plaintiff's claim because the actual malice standard, by definition, requires plaintiffs to demonstrate that the defendant subjectively doubted the truth of the publication. ${ }^{84}$ Moreover, evidence of journalists' thoughts and communication annong themselves is likely, im most cases, to be obtamable only from the journahists themselves. In short, a qualified privilege would afford the editorial process no more protection than no privilege at all. ${ }^{85}$

\section{The Effect of Other Discovery Privileges on the Sullivan Balance in Light of Herbert}

The most effective and most used inethod of proving actual malice is to present evidence of a libel defendant's objective behavior from which the trier of fact can infer the defendant's state of mind. Much of my argument, and that of the court of appeals, is based on the assumption that public figure libel plaintiffs have free access to all sources of objective evidence. Two related discovery developments-protection of journalists' confidential sources and nonconfidential, unpublished inaterials-cast doubt on this assumption, however.

\section{The Qualified Privilege Against Discovery of Confidential Sources}

The qualified privilege against discovery of the identities of confidential sources ${ }^{86}$ is not inconsistent with the assumption that libel plaintiffs have access to all sources of objective evidence. Although the qualified privilege establishes a high discovery threshold, it does not present an imsuperable barrier. If, after exhaustive discovery of nonconfidential, objective evidence, a plaintiff can demonstrate that the confidential source possesses information that is both critical to the success of his claim and cannot be obtamed from another source, then the journahist will be compelled to disclose the source's identity.

The qualified privilege for confidential sources is an accomodation of the press's need to gather information and the conflictimg needs of civil hitigants to obtain information that is relevant to their claims or defenses. Whether this policy resolution is desirable is beyond the

84. See note 82 supra.

85. It is for this reason, and because state of mind discovery affects the third Sullivan goal, that the absolute privilege established by Herbert is distinguishable from the qualified privilege recognized in the confidential source cases. See part IIB supra.

86. See part IIB supra. 
scope of this Note. ${ }^{87}$ As long as libel plaintiffs have some means of obtaining the identities of confidential sources, it is irrelevant to an analysis of Herbert whether such discovery is subject to the normal relevancy standard ${ }^{88}$ or to the Garland test. However the Supreme Court ultimately resolves the confidential source issue-short of granting an absolute privilege- libel plamtiffs will have access to all sources of objective evidence of the defendant's behavior from which actual malice can be inferred.

\section{Restrictive Discovery of Outtakes}

Another development that threatens the efficacy of the Herbert decision is the protection of journalistic "outtakes"-nonconfidential, unpublished materials such as reporters' notes, documents used during research, photographs, tapes, and film footage that was omitted from a broadcast. ${ }^{89}$ Several courts have extended the Garland test to discovery of outtakes, ${ }^{90}$ and several states have enacted "shield" laws that seem absolutely to protect unpublished material. ${ }^{91}$

These protections are not compatible with the Sullivan balance, particularly as it has been inodified by Herbert, and should not be applied to libel actions. ${ }^{92}$ First, as I have argued in this Note and as the court of appeals did in Herbert, objective evidence-such as material that was omitted from the broadcast or publication and the contents of journalists' conversations with sources-is highly probative of the defendant's state of mind, and is a much used source of proving actual

87. For a discussion of the benefits of a privilege for confidential sources, see Goodale, Branzburg v. Hayes and the Developing Qualified Privilege for Newsmen, 26 Hastings L.J. 709 (1975).

88. Fed. R. Civ. P. 26(b)(1).

89. In Herbert, the plaintiff had free access to all such material in the defendants' possession. 568 F.2d at $982-83$.

90. See, e.g., Loadholtz v. Fields, 389 F. Supp. 1299, 1303.(M.D. Fla. 1975) ("The compelled production of a reporter's resource materials is equally invidious as the compelled disclosure of his confidential informants."); Deinocratic National Committee v. McCord, 356 F. Supp. 1394 (D.D.C. 1973).

91. See, e.g., CAL. Evid. Code $\$ 1070$ (West Supp. 1977): “(a) A publisher, editor, [or] rcporter . . . cannot be adjudged in contempt by a judicial, legislative, [or] administrative body . . . (b) ... for refusing to disclose any.unpubhshed information obtained or prepared in gatherimg, receiving or processing of information for communication to the public"; N.J. REV. STAT. ANN. § 2A: 84A-21 (West Supp. 1978):

[A] person . . . elnployed by the news media for the purpose of gathering, . . . editing or disseminating the news . . . has a privilege to refuse to disclose, in any legal or quasilegal proceeding or before any investigative body...

-..

b. Any news or information obtained in the course of pursuing his professional activities whether or not it is disseminated.

92. The California shicld law, CAL. Evid. CoDE $§ 1070$, for example, was not intended to prevent "the use of other sanctions for refusal of a newsman to make discovery when he is a party to a civil proceeding." Comment-Assembly Committee on Judiciary, CAL. Evid. CoDE. $\$ 1070$ (West 1966). 
malice. Without such evidence, in inost cases it would be impossible for libel plaintiffs to carry their burden of proof. Second, discovery of nonconfidential inaterial would have the opposite effect on journalists' behavior than would state of mind discovery. In libel actions, members of the press attempt to demonstrate that they had thoroughly researched the allegedly libelous story and had fairly represented the plaintiff in the broadcast or publication. Thus, liberal discovery of the materials that coinpose the journalistic record should induce journalists both to research stories thoroughly and to edit fairly, and to inaintain a record of such activities. In short, discovery of outtakes in libel actions is consistent with the three Sullivan goals.

The proper standard for discovery of outtakes in libel actions is a showing of relevancy - the saine standard applied to inost civil discovery. Courts could, however, fashion other rules to protect the press that do not impair libel plaimtiffs' ability to prove actual malice. In Gilbert v. Allied Chemical Corp.,$^{93}$ for exanple, the district court refused to protect unpublished material froin discovery, but stated that it "has the power as well as the duty to fashion protective orders that enable the movant to secure the needed information at a minimum of public exposure to the subject of the subpoena . . . ."94

\section{IV}

\section{The Applicability of Herbert to Cases Governed by THE GERTZ NEgLIGENCE STANDARD}

The discussion thus far has been limited to libel actions in which the plaintiff is either a public official or a public figure and, therefore, inust ineet the Sullivan actual malice standard. If the plaintiff is a private figure, ${ }^{95}$ the Constitution requires only that he prove that the defendant negligently published false inaterial. ${ }^{96}$ In such cases, the argument for denying state of mind discovery is actually inore coinpelling than in cases like Herbert. Since private figure plaintiffs only have to prove negligence, they need direct state of mind evidence inucl less, because objective evidence is ainple to prove negligence. Instead of having to prove that the defendants published with doubts about the trutl of the story, private figure plaintiffs need prove only that the defendants' behavior fell short of reasonable and accepted journalistic standards.

93. 411 F. Supp. 505 (E.D. Va. 1976).

94. Id. at 511 .

95. For a definition of who is not a private figure, see note 68 supra.

96. In Gertz, the Supreme Court held that in libel actions involving private figure plaimtiffs the states are free to set any standard of hability at least as high as negligence. 418 U.S. 323, 347 (1974). Private figure plaintiffs seeking punitive damages inust prove actual malice, however. Id. at 349. In such cases, Herbert presumably would be applied. 
As I have argued, state of mind discovery would tend to discourage journalists from expressing tentative conclusions about an investigation, debating the veracity of a source, or playing the role of a devil's advocate because such information could be used as evidence that they doubted the trutl of the publication or broadcast. When the standard of liability is negligence, lowever, journalists could be found liable for not reflecting on and debating editorial decisions if such inaction is considered to fall short of reasonable and accepted journalistic standards. Thus, state of mind discovery would place journalists in a double bind: if they do question and debate editorial decisions, this information could be used to prove actual malice; if they do not, they could be found to have been negligent. To avoid this dilemina, the absolute privilege established in Herbert should be applied to libel cases im which the standard of liability is neghigence.

\section{CONCLUSION}

The court of appeals decision in Herbert to adopt an absolute privilege against state of mind discovery was correct because it is the result most consistent with the Sullivan balance. As long as libel plaintiffs can freely discover evidence of the defendant's objective behavior in preparimg the allegedly libelous material, they will not be hindered significantly by the prohibition on direct state of mind inquiry. Thus, Herbert only slightly impairs the compensatory goal of the Sullivan balance. In addition, Herbert promotes independant journalism by insulating the editorial process from judicial scrutiny. And Herbert promotes responsible journahisin by allowing journalists freely to question and express doubts about a story during the prepublication investigation and editing stages witlout fear that such thoughts or statements could later be used as evidence that they published the story with doubts about its accuracy.

Herbert presents the Supreine Court an opportumity to define inore clearly the three interests protected by Sullivan and to state more cogently the purposes of the Sullivan balance. And, if the Court affirms the absolute privilege against state of mind discovery, it would substantially promote those high purposes.

Brian E. Gray*

* B.A. 1976, Pomona College; third-year student, Boalt Hall School of Law; Editor-inChief, California Law Review. I would like to thank Cathy Gray for her editorial and secretarial assistance. 